\title{
Building an Ovary: Insights into Establishment of Somatic Cell Lineages in the Mouse
}

\author{
Barbara Nicol Humphrey H.-C. Yao \\ Laboratory of Reproductive and Developmental Toxicology, National Institute of Environmental Health Sciences, \\ Research Triangle Park, N.C., USA
}

\section{Key Words}

Development · FOXL2 - Granulosa cells · Ovary ·

Sex determination $\cdot$ Theca cells . WNT pathway

\begin{abstract}
The molecular pathways that drive the differentiation of somatic cell populations in the testis and ovary have been the subjects of intensive research over the past decade. It is now clear that ovarian differentiation is a coordinate event driven by secreted factors including R-spondin1, WNT4, and follistatin and transcriptional regulators such as $\beta$-catenin and FOXL2. These factors direct bipotential somatic cell lineages toward an ovarian fate and simultaneously suppress the emergence of testis-determining processes. This review summarizes the molecular pathways responsible for establishment of the ovary and discusses the current hypotheses on the origin(s) of somatic cell lineages and how these somatic cells acquire the characteristics necessary for their function during ovarian development and maintenance.
\end{abstract}

(c) 2014 S. Karger AG, Basel
During organogenesis, cells acquire tissue-specific identities that shape their developmental fate and future functions in a given organ. This process of cell fate specification is facilitated by coordinate interactions among numerous signals which originate from either the cell itself, or the surrounding environment, or both. Sex determination of the gonad is an ideal model for the study of cell lineage specification as 2 distinctively different organs (testis and ovary) arise from a common bipotential organ called the genital ridge or gonadal primordium. In mammals, expression of the testis-determining gene $S R Y$ (sex-determining region of the $\mathrm{Y}$ chromosome) tips the balance towards testis differentiation [Sinclair et al., 1990; Koopman et al., 1991; Albrecht and Eicher, 2001]. In a normal XX individual (or in the absence of the SRY gene), the bipotential gonad undergoes ovarian differentiation which eventually leads to the formation of follicles consisting of a single oocyte surrounded by somatic granulosa cells and theca cells. Over the past decade, significant progress has been made toward understanding ovarian differentiation at both the molecular and cellular level. This review focuses on the differentiation of the somatic compartment of the mammalian ovary, using the mouse as the model organism, with emphases on granulosa and theca cells populations, their potential fetal origins, and the molecular pathways that drive their differentiation and maintenance.

\section{KARGER}

E-Mail karger@karger.com

www.karger.com/sxd
(C) 2014 S. Karger AG, Basel

$1661-5425 / 14 / 0085-0243 \$ 39.50 / 0$
Humphrey H.-C. Yao

Laboratory of Reproductive and Developmental Toxicology

National Institute of Environmental Health Sciences

111 TW Alexander Drive, Mail Drop C4-10, Research Triangle Park, NC 27709 (USA)

E-Mail humphrey.yao@nih.gov 


\section{Morphological Changes from the Bipotential Gonad to an Ovary}

Around embryonic day 10 (E10) in the mouse, the somatic compartment of the bipotential gonad arises from the thickening of coelomic epithelium on the surface of the mesonephros, a transient nephric organ that later contributes to reproductive tract formation [Swain and LovellBadge, 1999; Kusaka et al., 2010]. Germ cells, in contrast to somatic cells, originate from the epiblast outside of the bipotential gonad [Ginsburg et al., 1990; Lawson and Hage, 1994; Lawson, 1999] and migrate into the bipotential gonad between E10.5 and E11.5. Gonadal sex determination in the mouse embryo starts at E10.5 with a transient expression of Sry in a particular somatic cell population that becomes the Sertoli cells, the supporting cell lineage in the testis [Sinclair et al., 1990; Koopman et al., 1991; Albrecht and Eicher, 2001]. As a consequence of SRY action, dramatic morphological changes (increased cell proliferation and formation of testis cords and the coelomic vessel) occur in the fetal testis. At this stage, the ovary is smaller than the testis, and ovarian morphology remains similar to the bipotential gonad. The first distinguishable sign of ovarian differentiation appears around E13.5 when germ cells enter meiosis in an anterior to posterior fashion [McLaren and Southee, 1997; Menke et al., 2003; Yao et al., 2003]. Female germ cells then arrest at prophase of meiosis I and initiate folliculogenesis close to the time of birth when they form primordial follicles [for a review see Edson et al., 2009]. Each primordial follicle is composed of a single oocyte surrounded by a layer of flattened supporting cells called granulosa cells. A basal lamina separates the oocyte and granulosa cells from the ovarian interstitium or mesenchyme. As follicles grow, the granulosa cells become cuboidal in the primary follicle and proliferate into multilayers in the secondary follicle and antral follicles. Starting at the secondary follicle stage, the steroidogenic cell population called theca cells appears and surrounds the granulosa cell layers outside of the basal lamina. The major role of these theca cells is to produce androgens that are converted to estrogens by the granulosa cells and to support vascularization of the follicle [Magoffin, 2005].

\section{Molecular Pathways That Drive Ovarian Differentiation and Maintenance}

Ovarian differentiation was once considered to be a default process that occurs in the absence of SRY. This perception is based on the fact that no histological trans- formation appears in the ovary during the time of sex determination, in contrast to the dramatic morphological changes in the testis at this time. Indeed, spontaneous human mutations and mouse genetic studies have uncovered numerous genes in the testis-determining pathway downstream of SRY [Vigier et al., 1989; Sinclair et al., 1990; Kent et al., 1996; Schafer et al., 1996; Colvin et al., 2001], further supporting the conclusion that testis formation is actively driven. In parallel to the role of SRY in testis determination, an ovarian determining $(\mathrm{Od})$ gene(s) was proposed to trigger ovarian differentiation, and that this gene is negatively regulated by the testis-determining gene in the XY gonads [Eicher and Washburn, 1983; Washburn and Eicher, 1983]. However, the identification of XX individuals that develop testes in the absence of the $S R Y$ gene offers a different view on how ovarian differentiation is initiated [McElreavey et al., 1993; Vaiman et al., 1996]. Such cases of ovary-to-testis sex reversal in the absence of $S R Y$ have led to the hypothesis that an ovaryspecific $Z$ gene inhibits the testis-determining pathway while promoting ovarian differentiation. In the testis, the $Z$ gene is suppressed by SRY, therefore allowing the progression of testis development [McElreavey et al., 1993]. Genetic analyses of ovary-to-testis sex reversal cases in human and animals have identified potential candidates for the $Z$ gene, including WNT4 [Vainio et al., 1999; Biason-Lauber et al., 2004, 2007], RSPO1 [Parma et al., 2006; Chassot et al., 2008; Tomizuka et al., 2008], and FOXL2 [Crisponi et al., 2001; Pailhoux et al., 2001, 2002]. In the mouse gonad, all of these cited genes are expressed in an ovary-specific pattern before any morphological changes are observed in the ovary [Nef et al., 2005].

Both Wnt4 and Rspo1 are already expressed in the somatic cells of the bipotential gonad, and their expression becomes ovary specific at E11.5 [Vainio et al., 1999; Parma et al., 2006]. Knockout mouse models reveal that WNT4 and RSPO1 are parts of a common signaling pathway that acts through $\beta$-catenin (fig. 1A). Global knockouts of Wnt4 and Rspol and somatic cell specific ablation of $\beta$-catenin all result in similar phenotypes in the ovary, characterized by the formation of testis-specific vasculature, appearance of ectopic adrenal cells, and a loss of germ cells [Vainio et al., 1999; Chassot et al., 2008; Tomizuka et al., 2008; Liu et al., 2009]. The involvement of $\beta$-catenin as a downstream regulator of WNT4 and RSPO1 is further supported by the observation that ectopic activation of $\beta$-catenin in the somatic cells of $W n t 4$ or Rspo1 knockout ovaries rescues the phenotypes of these mice [Chassot et al., 2008; Liu et al., 2010]. The expression of Wnt4, but not Rspo1, appears to be regulated in an au- 


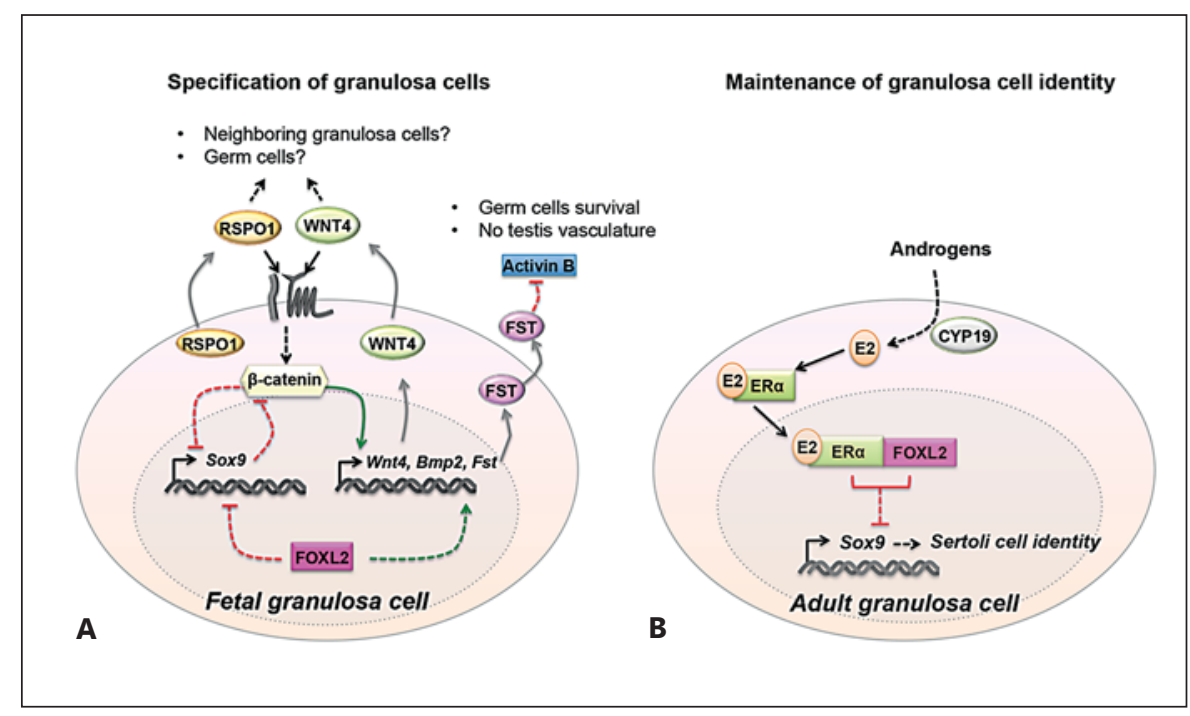

Fig. 1. Molecular pathways involved in granulosa cell specification and maintenance. A Fetal granulosa cell fate is driven primarily by 2 secreted proteins, RSPO1 and WNT4, which presumably act on the pregranulosa cells in an autocrine/paracrine manner. Based on the evidence from other model systems, WNT4/RSPO1 synergistically activate $\beta$-catenin that induces transcription of ovarian factors such as Fst, Bmp2, and Wnt4 itself. FST inhibits activin B which causes formation of testis-specific coelomic vessel and loss of female germ cells. In addition, the WNT4/RSPO $1 / \beta$-catenin pathway antagonizes the emergence of Sertoli cell fate by suppressing Sox9. Transcription factor FOXL2 alone does not have a determining role in ovarian specification in mice; however, it participates to some degree in the suppression of Sox 9 and activation of other ovarian genes such as Fst. B In the adult ovary, granulosa cell identity is maintained by FOXL2 and estrogen receptor (ER) which suppress the transcription of Sox9. ERa is activated by the presence of estrogens (E2) as a result of the conversion of androgens by the steroidogenic enzyme aromatase CYP19. tocrine or paracrine manner as the expression of Wnt4 is downregulated in the absence of Rspo1 or $\beta$-catenin [Chassot et al., 2008; Liu et al., 2009]. Additional downstream targets of the WNT4/RSPO1/ $\beta$-catenin pathway have been identified, including follistatin (Fst) and Bmp2 [Yao et al., 2004; Manuylov et al., 2008; Liu et al., 2009]. Fst expression is detected in the fetal mouse ovary as early as E11.5 [Menke and Page, 2002; Yao et al., 2004]. In addition to the WNT4/RSPO1/ $\beta$-catenin pathway, Fst is also cooperatively regulated by FOXL2 and BMP2 [Kashimada et al., 2011]. FST prevents the formation of testisspecific vasculature and germ cell death through inhibition of activin B [Yao et al., 2004, 2006; Liu et al., 2010]. At the molecular level, the WNT4/RSPO1/ $\beta$-catenin pathway exhibits similar anti-testis activity, a characteristic of the $Z$ factor. Without Wnt4 or Rspo1, fetal mouse ovaries show signs of sex reversal with the expression of testis markers Sox9 and Amh. This antagonism of Sox9 expression by the ovarian pathway could be due to the inhibitory capacity of $\beta$-catenin at the Sox 9 enhancer [Maatouk et al., 2008; Manuylov et al., 2008; Bernard et al., 2012]. There are also mutual antagonisms between Rspo1 and Sox9 and between Wnt4 and Fgf9 [Kim et al.,
2006; Jameson et al., 2012a; Lavery et al., 2012]. Removal of Rspo1 in the Sox 9 knockout testis restores testis development, indicating that Rspol is responsible for the testisto-ovary sex reversal in the Sox 9 knockout male [Lavery et al., 2012]. Similarly, loss of Wnt4 rescues the testis-toovary sex reversal in Fgf9 or Fgfr 2 knockout males [Jameson et al., 2012a]. Therefore, testis differentiation requires repression of Rspo1 and Wnt4, as expected for a potential $Z$ gene. However, similar to the Rspo1/Sox 9 double knockout, absence of $F g f 9$ does not rescue the sex reversal phenotype of Wnt4 knockout ovaries, suggesting that ovarian development requires repression of other masculinizing factors [Jameson et al., 2012a; Lavery et al., 2012].

The anti-testis nature of these ovarian genes is also demonstrated in the context of fetal testes. Overexpression of Wnt4 in fetal mouse testes affects testis vasculature and steroid production but is not sufficient to induce testis-to-ovary sex reversal [Jeays-Ward et al., 2003; Jordan et al., 2003]. However in humans, duplication of a portion of chromosome $1 \mathrm{p}$ that contains both WNT4 and RSPO1 is sufficient to disrupt testis differentiation and induce testis-to-ovary sex reversal [Jordan et al., 2001; Tevosian and Manuylov, 2008]. A similar testis-to-ovary sex 
reversal phenotype is observed in XY mice when $\beta$-catenin is ectopically expressed in the somatic cell lineage [Maatouk et al., 2008]. FOXL2 also has anti-testis properties, as its overexpression in the fetal testis results in disorganized seminiferous tubules and reduced expression of Sox9, Amh, and other testis-specific genes [Ottolenghi et al., 2007].

The involvement of the WNT4/RSPO1/ $\beta$-catenin pathway in early ovarian differentiation is beyond any doubt; however, it is worth noting that the phenotypes in Wnt4, Rspo1, and Ctnnb1 (coding for $\beta$-catenin) knockout ovaries are not identical. Although a weak and transient expression of Sox9 is detected in both Rspo1 and Wnt4 knockout ovaries at E11.5, a strong upregulation of Sox9 is only detected in Rspol knockout ovaries at the time of birth [Vainio et al., 1999; Kim et al., 2006; Ottolenghi et al., 2007; Chassot et al., 2008]. In addition, no upregulation of Sox9 expression is found in somatic cellspecific Ctnnb1 knockout ovaries [Manuylov et al., 2008; Liu et al., 2009]. These observations imply that the WNT4/ RSPO $1 / \beta$-catenin pathway is not linear and could involve other unknown factors in a synergistic or redundant manner.

While the initial establishment of ovarian somatic cell fate is controlled by the WNT4/RSPO $1 / \beta$-catenin pathway, differentiation and maintenance of ovarian somatic cell identity require the transcription factor FOXL2 [Schmidt et al., 2004; Ottolenghi et al., 2005]. Unlike Rspo1 or Wnt 4 knockout mice, inactivation of Foxl2 does not disturb early ovarian differentiation [Ottolenghi et al., 2005]. In the fetal mouse ovary, FOXL2 protein appears in the nuclei of some somatic cells at E12.5, and this expression is maintained through adult life in granulosa cells [Loffler et al., 2003]. The ovary-specific expression of Foxl2 is highly conserved among vertebrates [Baron et al., 2005]. In humans, mutations of the FOXL2 gene cause the blepharophimosis epicanthus inversus syndrome, characterized by premature ovarian failure among other symptoms [Crisponi et al., 2001]. The same ovarian phenotype is also observed in Foxl2 knockout mice in which follicles are arrested at the primordial stage as a result of the failure of granulosa cells to differentiate from a squamous to a cuboidal form [Schmidt et al., 2004; Uda et al., 2004]. In the adult ovary, granulosa cell identity requires FOXL2 as conditional ablation of Foxl2 leads to transdifferentiation of granulosa cells into Sertoli cells, characterized by the expression of Sertoli-cell specific markers such as Sox9 and Dmrt1 [Uhlenhaut et al., 2009]. A similar transdifferentiation phenotype is observed in the adult mouse ovary when estrogen signaling is inhibited. In the absence of the estrogen-producing enzyme aromatase (or Cyp19) or receptors for estrogen (estrogen receptor $\alpha$ and $\beta$ ), granulosa cells transdifferentiate into Sertoli cells in the adult ovary, yet early ovarian differentiation appears normal [Couse and Korach, 1999; Britt et al., 2001; Britt and Findlay, 2003]. In marsupials and some non-mammalian species, estrogen signaling prevents translocation of SOX9 into the nucleus, therefore blocking the initiation of testis differentiation [for a review see Pask, 2012]. In the adult mouse ovary, FOXL2 acts in conjunction with $\mathrm{ERa}$ as a direct transcriptional repressor of the testis pathway by binding to the regulatory sequence of Sox 9 [Uhlenhaut et al., 2009]. These genetic evidences demonstrate that, at least in mice, the differentiated state of adult granulosa cells is reversible, and FOXL2 and estrogen signaling serve as guardians of granulosa cell identity (fig. 1B).

The involvement of FOXL2 in ovarian differentiation seems to be a species-specific event. In female goats with polled intersex syndrome (PIS), a 11.7-kb DNA fragment that contains FOXL2 and 2 long non-coding RNAs is deleted [Pailhoux et al., 2001]. As a result of this deletion, the PIS females develop a complete ovary-to-testis sex reversal during fetal life, in contrast to the normal ovarian development observed in Foxl2 knockout mouse embryos [Pailhoux et al., 2002]. The difference in response to the loss of FOXL2 in these 2 species may be due to either an involvement of the 2 non-coding RNAs in the PIS goats or a difference in steroidogenic activity in the fetal ovaries between mouse and goat. Fetal mouse ovaries are steroidogenically inactive; however, the fetal goat ovary is capable of producing and responding to estrogens based on the expression of Cyp 19 and ER $\beta$ in pregranulosa cells [Pannetier et al., 2006]. The presence of both FOXL2 and estrogen signaling in the fetal goat ovary could result in an environment similar to that in the adult mouse ovary, where granulosa cells require both FOXL2 and the estrogen pathway to maintain their identities.

Although loss of Foxl2 does not appear to affect fetal ovarian differentiation in the mouse, subtle molecular changes are observed in the Foxl2 knockout fetal ovary. It shows an upregulation of testis-specific genes such as Sox9 and Inhbb and downregulation of ovarian genes such as Fst [Ottolenghi et al., 2007; Garcia-Ortiz et al., 2009]. Interestingly, double knockout of Wnt4 and Foxl2 or Rspo1 and Foxl2 leads to an earlier and more pronounced ovary-to-testis sex reversal phenotype than a single knockout of Wnt4 or Rspo1 [Ottolenghi et al., 2007; Auguste et al., 2011]. This observation suggests a complementary action between the WNT4/RSPO1 pathway and 
FOXL2 in ovarian differentiation. It is worth noting that no complete ovary-to-testis sex reversal is observed in these double knockout models, indicating the involvement of other unidentified factors. All these data accumulated over the years suggest that instead of a single $Z$ gene, multiple ovarian genes may act independently or synergistically to promote ovarian differentiation while suppressing the testis pathway.

\section{Granulosa Cells: Where Do They Come From?}

Different sources of granulosa cells in mammalian ovaries have been proposed, including the gonadal mesenchyme [Pinkerton et al., 1961], the mesonephros [Byskov and Lintern-Moore, 1973], or the surface epithelium [Gondos, 1975; Juengel et al., 2002; Sawyer et al., 2002]. In the bovine ovary, a particular cell type from the surface epithelium of the mesonephros has been shown to give rise to both granulosa cells and the surface epithelium of the ovary [Hummitzsch et al., 2013]. Evidence from a series of experiments utilizing chimeric mouse embryos led Burgoyne and colleagues to propose that Sertoli cells in the testis and granulosa cells in the ovary are derived from a common supporting cell lineage. This hypothesis is based on the findings that some XX somatic cells in the chimeric XX/XY testis become Sertoli cells, whereas some $\mathrm{XY}$ somatic cells in the chimeric XX/XY or XO/XY ovary differentiate into granulosa cells [Palmer and Burgoyne, 1991a, b; Patek et al., 1991]. Later studies involving a transgenic mouse model that contains an EGFP reporter gene under the control of the Sry promoter (termed Sry$E G F P$ ) further confirmed this hypothesis [Albrecht and Eicher, 2001]. Sry-EGFP-positive cells are detected in the bipotential gonads of both sexes immediately below the coelomic epithelium and extending to the center of gonads near the mesonephros. In the fetal ovary, Sry-EGFPpositive cells become granulosa cells in the primordial follicle and express FOXL2 [Mork et al., 2012]. These findings together demonstrate that the supporting cell types in the ovary share a common origin with their male counterparts and that both cell populations possess the molecular machinery necessary for the induction of Sry expression.

Although granulosa cells likely derive from a common supporting cell lineage in the bipotential gonad, emerging evidence suggests that the granulosa cell population is heterogeneous. Examining the same Sry-EGFP model described above, Mork et al. [2012] discovered that cells of the ovarian surface epithelium (or coelomic epithelium) move into the ovarian proper and then become positive for Sry-EGFP and FOXL2. However, some FOXL2-positive cells are Sry-EGFP negative, implying that these FOXL2-positive/Sry-EGFP negative cells come from different sources. This discovery leads to a new model of granulosa cell specification: in the bipotential gonad, some cells from the coelomic epithelium migrate into the mesenchyme at the center of the gonad and give rise to the first set of granulosa cells. These pregranulosa cells express FOXL2 and participate in the formation of primordial follicles in the medulla immediately after birth. During later fetal development and shortly after birth (E14.5 to postnatal day 4), some cells from the ovarian surface epithelium continue to move into the ovary and give rise to a second wave of granulosa cells. These cells will form the follicles in the cortex that are activated during adult life [for a schematic view of this model see Mork et al., 2012]. However, these findings do not exclude the possibility that somatic cells present in the bipotential gonad are also a source of granulosa cells. The concept of heterogeneous populations of granulosa cells is also corroborated by the findings by Auguste et al. [2011]. In the absence of Rspo1, FOXL2 expression is missing from the medial region of the ovary under the surface epithelium but is maintained in the other half of the ovary adjacent to the mesonephros. These data suggest that at least 2 different FOXL2-positive populations exist within the fetal ovary: one expressing Foxl2 in an Rspo1-dependent manner under the surface epithelium, and the other population expressing Foxl2 independent of Rspo1 close to the mesonephros. Heterogeneity within granulosa cells population was further brought to light by Harikae et al. [2013]. They identified a subpopulation of pre-granulosa cells that continuously retains an 'SRY-dependent SOX9inducibility' (SDSI) throughout fetal and early postnatal stages whereas this ability should be lost by E12.5. Interestingly, these SDSI-positive pre-granulosa cells are located near the mesonephros and participate in the formation of primordial follicles in the medulla at birth, similarly to the first set of FOXL2-positive granulosa cells observed by Mork et al. [2012]. A study of the developmental dynamics of primordial follicles described the presence of 2 populations of follicles with one population in the medulla that is simultaneously activated right after birth and the other population in the cortex that is progressively activated throughout adulthood [Zheng et al., 2013]. This study seems to support the notion that the first wave of granulosa cells contributes to folliculogenesis in the medulla, whereas the second wave of granulosa cells participates in follicle formation in the cortex. 
Examination of the expression patterns of various ovary-specific genes reveals an even more complicated picture of the composition of the somatic cell populations in the fetal ovary. For example, Rspol mRNA is present throughout the fetal ovary including the ovarian surface epithelium, whereas Wnt4, Foxl2, and Fst are expressed in the ovarian proper but not in the surface epithelium domain [Chen et al., 2012]. Bmp2, another ovary-specific gene, is produced by a population of cells located right underneath the surface epithelium [Yao et al., 2004]. Celltype specific microarray analysis showed that $B m p 2$ is expressed in a variety of somatic cell lineages in the fetal ovary, including the Sry-EGFP population, suggesting that some Bmp2-positive cells belong to the pregranulosa cell population [Jameson et al., 2012b]. One explanation for the diverse expression pattern of ovarian genes is that it simply reflects the differentiation progress of one somatic cell population. However, the simultaneous expression of these genes in different domains of the ovary argues against this hypothesis. Instead, these data seem to favor the notion that granulosa cells are composed of different sub-populations expressing slightly different sets of genes. Whether these different sub-population of cells have unique functions remains to be determined.

\section{Theca Cells, the Other Major Somatic Cell Type of the Follicle}

Theca cells are fibroblast-like flattened cells that constitute the vascularized and steroidogenic layers of the mature follicle. Mature theca cells are characterized by expression of luteinizing hormone receptor (LHR) and genes involved in steroidogenesis (steroidogenesis acute regulatory protein (STAR), CYP17A1, CYP11A1, and HSD3B) [Magoffin and Weitsman, 1993]. Theca cells synthesize androgens which are then converted into estrogens by granulosa cells [Erickson et al., 1985]. These steroidogenic enzymes are used as markers for theca cells in the adult ovary and are first detected adjacent to early secondary follicles, suggesting that theca cells are only activated postnatally [Magoffin and Magarelli, 1995]. In vitro studies using the bovine or human ovarian stromal tissue show that recruitment and activation of theca cells from the stroma requires pituitary-derived LH and local factors including insulin-like growth factor (IGF), KIT ligand, and growth differentiation factor 9 (GDF9) [for a review see Young and McNeilly, 2010]. In particular, the oocyte-derived GDF9 appears to be involved in theca cell differentiation, as the folliculogenesis in Gdf9 knockout mouse and GDF9 mutant sheep arrests at the primary stage, and theca cell recruitment is blocked [Dong et al., 1996; Elvin et al., 1999; Nicol et al., 2009]. GDF9 may act directly on theca cells or indirectly through the stimulation of specific molecular pathways by the granulosa cells [Elvin et al., 1999]. Indeed, granulosa cells secrete various factors, such as KIT ligand or IGF, which are involved in theca cell recruitment and activation [for a review see Young and McNeilly, 2010]. When co-cultured with granulosa cells, stromal cells from the mature bovine ovary differentiate into theca cells, suggesting that precursors of the theca cells are present in the mesenchyme of the ovary [Orisaka et al., 2006]. Honda et al. [2007] isolated and cultured putative theca cell precursors from neonatal mouse ovaries. When exposed to granulosa-cell conditioned medium or a cocktail of IGF, KIT ligand, and GDF9, these cells expressed markers of theca cells. Moreover, when transplanted into donor ovaries, these differentiated cells integrated into the theca cell layers of follicles. Thus, the theca cell lineage appears to be already determined at the onset of folliculogenesis.

Similar to the hypothesis that a common precursor exists for the somatic supporting cells in the testis and ovary (Sertoli cells vs. granulosa cells), a common precursor for steroidogenic cells (Leydig cells in the testis and theca cells in the ovary) is suspected. In the testis, some Leydig cell precursors appear to be present already at the bipotential stage, as these gonads are able to produce testosterone in culture [Merchant-Larios et al., 1993]. In search for the progenitor population of the interstitial cells in the gonads, DeFalco et al. [2011] uncovered that 2 MAF transcription factors (MAFB and C-MAF) mark the interstitial cell population in both fetal testes and ovaries. Cell lineage tracing of these markers showed that distinct progenitor lineages, the surface epithelium and an unknown cell type along the vascularized gonad-mesonephros border, give rise to the interstitial/stromal compartment of the gonad, and that some of these cells can differentiate into fetal Leydig cells in the testis. In the fetal ovary, the MAFB/C-MAF-positive cells are negative for the granulosa cell lineage marker FOXL2, suggesting that they could be the progenitors for the theca cells.

Based on their similar steroidogenic activity and regulation, knowledge on how the Leydig cell population is established could be applied to understand how theca cell differentiation is initiated. The signaling pathway induced by the ligand Desert hedgehog (DHH) is responsible for the specification of fetal Leydig cells in mice and rats [Pierucci-Alves et al., 2001; Kawai et al., 2011]. Mutations or loss of Dhh lead to decreased Leydig cell numbers 
and consequent androgen deficiency [Pierucci-Alves et al., 2001; Yao et al., 2002]. Moreover, chemical inhibition of the hedgehog pathway abolishes the fetal Leydig cell population, suggesting that other hedgehog ligands are required for Leydig cell development [Yao and Capel, 2002; Barsoum and Yao, 2011]. The hedgehog pathway acts through its receptor PTCH1 and intracellular regulator GLI1. In the postnatal and adult mouse ovary, theca cells are positive for Ptch 1 and Gli1, while the ligands Dhh and Indian hedgehog (Ihh) are produced by the granulosa cells [Wijgerde et al., 2005]. Moreover, in vitro culture of bovine theca cells in the presence of Sonic hedgehog induces cell proliferation, androgen synthesis, and Gli1 expression [Spicer et al., 2009]. These evidences implicate a potential role for the hedgehog pathway in theca cell differentiation in the ovary.

\section{Conclusions and Perspectives}

With the molecular mechanisms underlying ovarian differentiation gradually coming to light, new questions emerge regarding where these factors are produced and how they act to control the establishment of various somatic cell lineages. The unique expression patterns of Wnt4, Rspo 1, Foxl2, and other ovary-specific genes imply the presence of subpopulations of granulosa cells. Identification of lineage markers for the interstitial cells reveals that potential progenitors of theca cells reside in the fetal ovary long before their differentiated progeny appear in the adult ovary. The origins of somatic cells in the ovary are more complex than expected, with probably multiple sources for both granulosa and theca cells. The surface epithelium that encloses the gonad, mesenchymal cells that are already present in the gonads, or cells that migrate from the mesonephros are potential contributors to the somatic cell lineages. Cell tracing of early markers of somatic cells is a powerful tool to uncover the origins of theca or granulosa cell populations, and recent studies using this strategy provide promising results [DeFalco et al., 2011; Liu et al., 2012; Mork et al., 2012]. Cell-specific microarrays lead to the identification of many novel genes specifically expressed in the somatic compartment of the ovary at the time of sex determination [Bouma et al., 2004; Jorgensen and Gao, 2005; Nef et al., 2005; Beverdam and Koopman, 2006; Chen et al., 2012; Jameson et al., 2012b]. Challenges await us to identify the functional roles of these novel candidates and to connect the molecular pathways with cell fate specification processes that ultimately determine the identities of ovarian cells.

\section{Acknowledgements}

We thank all the members of the Yao lab for their helpful comments. This research was supported by the Intramural Research Program of the NIH, National Institute of Environmental Health Sciences.

\section{References}

Albrecht KH, Eicher EM: Evidence that Sry is expressed in pre-Sertoli cells and Sertoli and granulosa cells have a common precursor. Dev Biol 240:92-107 (2001)

-Auguste A, Chassot AA, Gregoire EP, Renault L, Pannetier M, et al: Loss of R-spondin1 and Foxl2 amplifies female-to-male sex reversal in XX mice. Sex Dev 5:304-317 (2011).

-Baron D, Batista F, Chaffaux S, Cocquet J, Cotinot C, et al: Foxl2 gene and the development of the ovary: a story about goat, mouse, fish and woman. Reprod Nutr Dev 45:377-382 (2005).

- Barsoum I, Yao HH: Redundant and differential roles of transcription factors Gli1 and Gli2 in the development of mouse fetal Leydig cells. Biol Reprod 84:894-899 (2011).

- Bernard P, Ryan J, Sim H, Czech DP, Sinclair AH, et al: Wnt signaling in ovarian development inhibits Sf1 activation of Sox9 via the Tesco enhancer. Endocrinology 153:901-912 (2012).
Beverdam A, Koopman P: Expression profiling of purified mouse gonadal somatic cells during the critical time window of sex determination reveals novel candidate genes for human sexual dysgenesis syndromes. Hum Mol Genet 15:417-431 (2006).

Biason-Lauber A, Konrad D, Navratil F, Schoenle EJ: A WNT4 mutation associated with Mullerian-duct regression and virilization in a 46,XX woman. N Engl J Med 351:792-798 (2004).

Biason-Lauber A, De Filippo G, Konrad D, Scarano G, Nazzaro A, Schoenle EJ: WNT4 deficiency - a clinical phenotype distinct from the classic Mayer-Rokitansky-Kuster-Hauser syndrome: a case report. Hum Reprod 22: 224-229 (2007).

Bouma GJ, Hart GT, Washburn LL, Recknagel AK, Eicher EM: Using real time RT-PCR analysis to determine multiple gene expression patterns during $\mathrm{XX}$ and $\mathrm{XY}$ mouse fetal gonad development. Gene Expr Patterns 5: 141-149 (2004).
Britt KL, Findlay JK: Regulation of the phenotype of ovarian somatic cells by estrogen. Mol Cell Endocrinol 202:11-17 (2003).

Britt KL, Drummond AE, Dyson M, Wreford NG, Jones ME, et al: The ovarian phenotype of the aromatase knockout (ArKo) mouse. J Steroid Biochem Mol Biol 79:181-185 (2001).

Byskov AG, Lintern-Moore S: Follicle formation in the immature mouse ovary: the role of the rete ovarii. J Anat 116:207-217 (1973).

Chassot AA, Ranc F, Gregoire EP, Roepers-Gajadien HL, Taketo MM, et al: Activation of beta-catenin signaling by Rspo1 controls differentiation of the mammalian ovary. Hum Mol Genet 17:1264-1277 (2008).

-Chen H, Palmer JS, Thiagarajan RD, Dinger ME, Lesieur E, et al: Identification of novel markers of mouse fetal ovary development. PLoS One 7:e41683 (2012).

Colvin JS, Green RP, Schmahl J, Capel B, Ornitz DM: Male-to-female sex reversal in mice lacking fibroblast growth factor 9. Cell 104:875889 (2001). 
Couse JF, Korach KS: Estrogen receptor null mice: what have we learned and where will they lead us? Endocr Rev 20:358-417 (1999).

Crisponi L, Deiana M, Loi A, Chiappe F, Uda M, et al: The putative forkhead transcription factor FOXL2 is mutated in blepharophimosis/ ptosis/epicanthus inversus syndrome. Nat Genet 27:159-166 (2001).

DeFalco T, Takahashi S, Capel B: Two distinct origins for Leydig cell progenitors in the fetal testis. Dev Biol 352:14-26 (2011).

Dong J, Albertini DF, Nishimori K, Kumar TR, Lu N, Matzuk MM: Growth differentiation factor-9 is required during early ovarian folliculogenesis. Nature 383:531-535 (1996).

-Edson MA, Nagaraja AK, Matzuk MM: The mammalian ovary from genesis to revelation. Endocr Rev 30:624-712 (2009).

Eicher EM, Washburn LL: Inherited sex reversal in mice: identification of a new primary sexdetermining gene. J Exp Zool 228:297-304 (1983).

-Elvin JA, Yan CN, Wang P, Nishimori K, Matzuk MM: Molecular characterization of the follicle defects in the growth differentiation factor 9-deficient ovary. Mol Endocrinol 13:10181034 (1999).

-Erickson GF, Magoffin DA, Dyer CA, Hofeditz C: The ovarian androgen producing cells: a review of structure/function relationships. Endocr Rev 6:371-399 (1985).

Garcia-Ortiz JE, Pelosi E, Omari S, Nedorezov T, Piao Y, et al: Foxl2 functions in sex determination and histogenesis throughout mouse ovary development. BMC Dev Biol 9:36 (2009).

- Ginsburg M, Snow MH, McLaren A: Primordial germ cells in the mouse embryo during gastrulation. Development 110:521-528 (1990).

Gondos B: Surface epithelium of the developing ovary. Possible correlation with ovarian neoplasia. Am J Pathol 81:303-321 (1975).

-Harikae K, Miura K, Shinomura M, Matoba S, Hiramatsu $\mathrm{R}$, et al: Heterogeneity in sexual bipotentiality and plasticity of granulosa cells in developing mouse ovaries. J Cell Sci 126: 2834-2844 (2013).

- Honda A, Hirose M, Hara K, Matoba S, Inoue K, et al: Isolation, characterization, and in vitro and in vivo differentiation of putative thecal stem cells. Proc Natl Acad Sci USA 104: 12389-12394 (2007).

-Hummitzsch K, Irving-Rodgers HF, Hatzirodos N, Bonner W, Sabatier L, et al: A new model of development of the mammalian ovary and follicles. PLoS One 8:e55578 (2013).

-Jameson SA, Lin YT, Capel B: Testis development requires the repression of WNT4 by FGF signaling. Dev Biol 370:24-32 (2012a).

-Jameson SA, Natarajan A, Cool J, DeFalco T, Maatouk DM, et al: Temporal transcriptional profiling of somatic and germ cells reveals biased lineage priming of sexual fate in the fetal mouse gonad. PLoS Genet 8:e1002575 (2012b).
Jeays-Ward K, Hoyle C, Brennan J, Dandonneau M, Alldus G, et al: Endothelial and steroidogenic cell migration are regulated by WNT4 in the developing mammalian gonad. Development 130:3663-3670 (2003).

Jordan BK, Mohammed M, Ching ST, Delot E, Chen XN, et al: Up-regulation of WNT-4 signaling and dosage-sensitive sex reversal in humans. Am J Hum Genet 68:1102-1109 (2001).

Jordan BK, Shen JH, Olaso R, Ingraham HA, Vilain E: WNT4 overexpression disrupts normal testicular vasculature and inhibits testosterone synthesis by repressing steroidogenic factor 1/beta-catenin synergy. Proc Natl Acad Sci USA 100:10866-10871 (2003).

Jorgensen JS, Gao L: Irx3 is differentially up-regulated in female gonads during sex determination. Gene Expr Patterns 5:756-762 (2005).

Juengel JL, Sawyer HR, Smith PR, Quirke LD, Heath DA, et al: Origins of follicular cells and ontogeny of steroidogenesis in ovine fetal ovaries. Mol Cell Endocrinol 191:1-10 (2002).

Kashimada K, Pelosi E, Chen H, Schlessinger D, Wilhelm D, Koopman P: FOXL2 and BMP2 act cooperatively to regulate Follistatin gene expression during ovarian development. Endocrinology 152:272-280 (2011).

Kawai Y, Noguchi J, Akiyama K, Takeno Y, Fujiwara Y, et al: A missense mutation of the Dhh gene is associated with male pseudohermaphroditic rats showing impaired Leydig cell development. Reproduction 141:217-225 (2011).

Kent J, Wheatley SC, Andrews JE, Sinclair AH, Koopman P: A male-specific role for SOX9 in vertebrate sex determination. Development 122:2813-2822 (1996).

Kim Y, Kobayashi A, Sekido R, DiNapoli L, Brennan J, et al: FGF9 and WNT4 act as antagonistic signals to regulate mammalian sex determination. Plos Biol 4:e187 (2006).

Koopman P, Gubbay J, Vivian N, Goodfellow P, Lovell-Badge R: Male development of chromosomally female mice transgenic for Sry. Nature 351:117-121 (1991).

Kusaka M, Katoh-Fukui Y, Ogawa H, Miyabayashi K, Baba T, et al: Abnormal epithelial cell polarity and ectopic epidermal growth factor receptor (EGFR) expression induced in $\mathrm{Emx} 2$ KO embryonic gonads. Endocrinology 151: 5893-5904 (2010).

Lavery R, Chassot AA, Pauper E, Gregoire EP, Klopfenstein M, et al: Testicular differentiation occurs in absence of R-spondin 1 and Sox9 in mouse sex reversals. PLoS Genet 8:e1003170 (2012).

Lawson KA: Fate mapping the mouse embryo. Int J Dev Biol 43:773-775 (1999).

Lawson KA, Hage WJ: Clonal analysis of the origin of primordial germ cells in the mouse. Ciba Found Symp 182:68-84; discussion 8491 (1994)
Liu C, Paczkowski M, Othman M, Yao HH: Investigating the origins of somatic cell populations in the perinatal mouse ovaries using genetic lineage tracing and immunohistochemistry. Methods Mol Biol 825:211-221 (2012).

Liu CF, Bingham N, Parker K, Yao HH: Sex-specific roles of beta-catenin in mouse gonadal development. Hum Mol Genet 18:405-417 (2009).

Liu CF, Parker K, Yao HH: WNT4/beta-catenin pathway maintains female germ cell survival by inhibiting activin betaB in the mouse fetal ovary. PLoS One 5:e10382 (2010).

Loffler KA, Zarkower D, Koopman P: Etiology of ovarian failure in blepharophimosis ptosis epicanthus inversus syndrome: FOXL2 is a conserved, early-acting gene in vertebrate ovarian development. Endocrinology 144: 3237-3243 (2003).

Maatouk DM, DiNapoli L, Alvers A, Parker KL, Taketo MM, Capel B: Stabilization of betacatenin in XY gonads causes male-to-female sex-reversal. Hum Mol Genet 17:2949-2955 (2008).

Magoffin DA: Ovarian theca cell. Int J Biochem Cell Biol 37:1344-1349 (2005).

-Magoffin DA, Magarelli PC: Preantral follicles stimulate luteinizing hormone independent differentiation of ovarian theca-interstitial cells by an intrafollicular paracrine mechanism. Endocrine 3:107-112 (1995).

Magoffin DA, Weitsman SR: Differentiation of ovarian theca-interstitial cells in vitro: regulation of 17 alpha-hydroxylase messenger ribonucleic acid expression by luteinizing hormone and insulin-like growth factor-I. Endocrinology 132:1945-1951 (1993).

- Manuylov NL, Smagulova FO, Leach L, Tevosian SG: Ovarian development in mice requires the GATA4-FOG2 transcription complex. Development 135:3731-3743 (2008).

McElreavey K, Vilain E, Abbas N, Herskowitz I, Fellous M: A regulatory cascade hypothesis for mammalian sex determination: SRY represses a negative regulator of male development. Proc Natl Acad Sci USA 90:3368-3372 (1993).

McLaren A, Southee D: Entry of mouse embryonic germ cells into meiosis. Dev Biol 187: 107-113 (1997).

Menke DB, Page DC: Sexually dimorphic gene expression in the developing mouse gonad. Gene Expr Patterns 2:359-367 (2002).

Menke DB, Koubova J, Page DC: Sexual differentiation of germ cells in XX mouse gonads occurs in an anterior-to-posterior wave. Dev Biol 262:303-312 (2003).

Merchant-Larios H, Moreno-Mendoza N, Buehr $\mathrm{M}$ : The role of the mesonephros in cell differentiation and morphogenesis of the mouse fetal testis. Int J Dev Biol 37:407-415 (1993).

-Mork L, Maatouk DM, McMahon JA, Guo JJ, Zhang $\mathrm{P}$, et al: Temporal differences in granulosa cell specification in the ovary reflect distinct follicle fates in mice. Biol Reprod 86:37 (2012). 
-Nef S, Schaad O, Stallings NR, Cederroth CR, Pitetti JL, et al: Gene expression during sex determination reveals a robust female genetic program at the onset of ovarian development. Dev Biol 287:361-377 (2005).

- Nicol L, Bishop SC, Pong-Wong R, Bendixen C, Holm LE, et al: Homozygosity for a single base-pair mutation in the oocyte-specific GDF9 gene results in sterility in thoka sheep. Reproduction 138:921-933 (2009).

-Orisaka M, Tajima K, Mizutani T, Miyamoto K, Tsang BK, et al: Granulosa cells promote differentiation of cortical stromal cells into theca cells in the bovine ovary. Biol Reprod 75:734740 (2006).

-Ottolenghi C, Omari S, Garcia-Ortiz JE, Uda M, Crisponi $\mathrm{L}$, et al: FOXL2 is required for commitment to ovary differentiation. Hum Mol Genet 14:2053-2062 (2005).

-Ottolenghi C, Pelosi E, Tran J, Colombino M, Douglass E, et al: Loss of WNT4 and FOXL2 leads to female-to-male sex reversal extending to germ cells. Hum Mol Genet 16:27952804 (2007).

- Pailhoux E, Vigier B, Chaffaux S, Servel N, Taourit $\mathrm{S}$, et al: A $11.7-\mathrm{kb}$ deletion triggers intersexuality and polledness in goats. Nat Genet 29:453-458 (2001).

-Pailhoux E, Vigier B, Vaiman D, Servel N, Chaffaux $\mathrm{S}$, et al: Ontogenesis of female-to-male sex-reversal in XX polled goats. Dev Dyn 224: 39-50 (2002).

- Palmer SJ, Burgoyne PS: In situ analysis of fetal, prepuberal and adult XX-XY chimaeric mouse testes: Sertoli cells are predominantly, but not exclusively, XY. Development 112: 265-268 (1991a).

- Palmer SJ, Burgoyne PS: XY follicle cells in the ovaries of $\mathrm{XO} / \mathrm{XY}$ and $\mathrm{XO} / \mathrm{XY} / \mathrm{XYY}$ mosaic mice. Development 111:1017-1019 (1991b).

- Pannetier M, Fabre S, Batista F, Kocer A, Renault $L$, et al: FOXL2 activates $P 450$ aromatase gene transcription: towards a better characterization of the early steps of mammalian ovarian development. J Mol Endocrinol 36:399-413 (2006).

- Parma P, Radi O, Vidal V, Chaboissier MC, Dellambra E, et al: $\mathrm{R}$-spondin1 is essential in sex determination, skin differentiation and malignancy. Nat Genet 38:1304-1309 (2006).

Pask AJ: A role for estrogen in somatic cell fate of the mammalian gonad. Chromosome Res 20: 239-245 (2012).
Patek CE, Kerr JB, Gosden RG, Jones KW, Hardy $\mathrm{K}$, et al: Sex chimaerism, fertility and sex determination in the mouse. Development 113: 311-325 (1991).

- Pierucci-Alves F, Clark AM, Russell LD: A developmental study of the desert hedgehog-null mouse testis. Biol Reprod 65:1392-1402 (2001).

Pinkerton JH, McKay DG, Adams EC, Hertig AT: Development of the human ovary-a study using histochemical technics. Obstet Gynecol 18:152-181 (1961).

Sawyer HR, Smith P, Heath DA, Juengel JL, Wakefield SJ, McNatty KP: Formation of ovarian follicles during fetal development in sheep. Biol Reprod 66:1134-1150 (2002).

-Schafer AJ, Foster JW, Kwok C, Weller PA, Guioli S, Goodfellow PN: Campomelic dysplasia with XY sex reversal: diverse phenotypes resulting from mutations in a single gene. Ann N Y Acad Sci 785:137-149 (1996).

- Schmidt D, Ovitt CE, Anlag K, Fehsenfeld S, Gredsted L, et al: The murine winged-helix transcription factor Foxl2 is required for granulosa cell differentiation and ovary maintenance. Development 131:933-942 (2004).

- Sinclair AH, Berta P, Palmer MS, Hawkins JR, Griffiths BL, et al: A gene from the human sex-determining region encodes a protein with homology to a conserved DNA-binding motif. Nature 346:240-244 (1990).

- Spicer LJ, Sudo S, Aad PY, Wang LS, Chun SY, et al: The hedgehog-patched signaling pathway and function in the mammalian ovary: a novel role for hedgehog proteins in stimulating proliferation and steroidogenesis of theca cells. Reproduction 138:329-339 (2009).

-Swain A, Lovell-Badge R: Mammalian sex determination: a molecular drama. Genes Dev 13: 755-767 (1999).

Tevosian SG, Manuylov NL: To beta or not to beta: canonical beta-catenin signaling pathway and ovarian development. Dev Dyn 237: 3672-3680 (2008).

Tomizuka K, Horikoshi K, Kitada R, Sugawara Y, Iba Y, et al: R-spondin1 plays an essential role in ovarian development through positively regulating WNT-4 signaling. Hum Mol Genet 17:1278-1291 (2008).

-Uda M, Ottolenghi C, Deiana M, Kimber W, Forabosco A, et al: Foxl2 disruption causes mouse ovarian failure by pervasive blockage of follicle development. Hum Mol Genet 13: 1171-1181 (2004).
Uhlenhaut NH, Jakob S, Anlag K, Eisenberger T, Sekido R, et al: Somatic sex reprogramming of adult ovaries to testes by FOXL2 ablation. Cell 139:1130-1142 (2009).

Vaiman D, Koutita O, Oustry A, Elsen JM, Manfredi E, et al: Genetic mapping of the autosomal region involved in XX sex-reversal and horn development in goats. Mamm Genome 7:133-137 (1996).

-Vainio S, Heikkila M, Kispert A, Chin N, McMahon AP: Female development in mammals is regulated by WNT-4 signalling. Nature 397: 405-409 (1999).

Vigier B, Forest MG, Eychenne B, Bezard J, Garrigou $\mathrm{O}$, et al: Anti-Mullerian hormone produces endocrine sex reversal of fetal ovaries. Proc Natl Acad Sci USA 86:3684-3688 (1989).

-Washburn LL, Eicher EM: Sex reversal in XY mice caused by dominant mutation on chromosome 17. Nature 303:338-340 (1983).

Wijgerde M, Ooms M, Hoogerbrugge JW, Grootegoed JA: Hedgehog signaling in mouse ovary: indian hedgehog and desert hedgehog from granulosa cells induce target gene expression in developing theca cells. Endocrinology 146:3558-3566 (2005).

Yao HH, Capel B: Disruption of testis cords by cyclopamine or forskolin reveals independent cellular pathways in testis organogenesis. Dev Biol 246:356-365 (2002).

-Yao HH, Whoriskey W, Capel B: Desert hedgehog/patched 1 signaling specifies fetal Leydig cell fate in testis organogenesis. Genes Dev 16: 1433-1440 (2002).

-Yao HH, DiNapoli L, Capel B: Meiotic germ cells antagonize mesonephric cell migration and testis cord formation in mouse gonads. Development 130:5895-5902 (2003).

-Yao HH, Matzuk MM, Jorgez CJ, Menke DB, Page DC, et al: Follistatin operates downstream of WNT4 in mammalian ovary organogenesis. Dev Dyn 230:210-215 (2004).

-Yao HH, Aardema J, Holthusen K: Sexually dimorphic regulation of inhibin beta $B$ in establishing gonadal vasculature in mice. Biol Reprod 74:978-983 (2006).

Young JM, McNeilly AS: Theca: the forgotten cell of the ovarian follicle. Reproduction 140:489504 (2010).

Zheng W, Zhang H, Gorre N, Risal S, Shen Y, Liu K: Two classes of ovarian primordial follicles exhibit distinct developmental dynamics and physiological functions. Hum Mol Genet [Epub ahead of print] (2013). 